\title{
Understanding public support for recycling policy: To unveil the political side of influence and implications
}

\begin{abstract}
Policy support from the public is gaining importance for successful implementation of environmental policy. Yet the underlying factors of policy support for environmental policy have not been comprehensively examined. While considerable number of studies offered explanation of the phenomenon from the perspective of environmental psychology and social psychology, the growing attention to political factors has not been adequately addressed. In light of this, the present study systematically identified political factors and integrated them with psychological attributes to build a conceptual model for investigating level of policy support for recycling policy. A random household telephone survey was conducted in Hong Kong. 504 valid responses were collected for model testing. The results suggested that although psychological attributes, attitude and perceived benefits, are significant in predicting recycling policy support, political factors are stronger predictors, which perceived policy effectiveness, policy fairness, policy preference, and participatory process demonstrated a significant effect on the level of policy support. In addition, the explanatory power of the conceptual model remarkably increased after political factors were added to the model. The model enables us to compare effects of different sources on the level of policy support, in turn, advances our understanding of the phenomenon. In addition to shaping positive attitude towards recycling and enhancing perceived benefits of recycling practices among the public, policy-makers should put more efforts in formulating a fair, responsive recycling policy that demonstrates capability of policy goal attainment. Public involvement during policy formulation stage is highly encouraged for mobilizing greater public support.
\end{abstract}

Keywords: waste recycling; waste management; public support; environmental policy; Hong Kong

\section{Introduction}

Policy support has been gaining increasing concern in waste management domain (e.g., Dunne, Convery, \& Gallagher, 2008; Triguero, Álvarez-Aledo, \& Cuerva, 2016; Wan, Shen, \& Yu, 2015; Xiao, Zhang, Zhu, \& Lin, 2017). It is essential to make an environmental policy feasible (de Groot \& Schuitema, 2012). Public opposition is a barrier to seamless implementation of policy (Cherry, Kallbekken, \& Kroll, 2012; Rauwald \& Moore, 2002); without public support, policies addressing environmental problems are likely to end in failure (Wan, Shen, \& Choi, 2017). Therefore, to obtain an in-depth understanding of factors that provoke public support for recycling policy is of utmost importance.

Stern (2000) defined policy support as a form of non-activist environmental behavior which people accept or support environment policies. It has been classified as an indirect proenvironmental behavior because showing support to the policy would benefit the environment or mitigate the environmental problems (Kollmuss \& Agyeman, 2002). To accept or support a policy denotes that an individual will make material sacrifices or change his/her behavioral patterns to achieve policy goals (Stern, Dietz, Abel, Guagnano, \& Kalof, 1999). Typical examples of policy support are willingness to pay a higher environmental taxes, changing personal behaviors in accordance with policy prescriptions, and indicating approval of environmental regulations (Stern, 2000; Wan et al., 2015).

Page 1 of 27 
Though investigation of policy support for environmental policy has been gaining more attention, there is a lack of systematic examination of the concept and the concept has rarely been studied with the purpose of building conceptual models. Many previous works restricted their investigations to identifying potential factors explaining variance in policy support and examined the predictability of these factors (e.g., de Groot \& Schuitema, 2012; Keramitsoglou \& Tsagarakis, 2013; Tobler, Visschers, \& Siegrist, 2012; Wan et al., 2015). A great variety of variables were identified; however, results and drawn conclusions are fragmentary, incomprehensive, and difficult to conceptualize, which fail to provide researchers with a solid theoretical foundation for additional exploration of the phenomenon (cf. Barr, 2007). Moreover, most established works suffer from conceptual bias. Since policy support was first defined as an environmental behavior by Stern (2000), research has targeted social psychological factors to reach possible explanations of the phenomenon (e.g., Rauwald \& Moore, 2002; Steg, Dreijerink, \& Abrahamse, 2005; Stern et al., 1999; Wan et al., 2015). Though studies investigating effects of policy features and political environment can also be found in current literature, attention given to these factors is far from enough. Given that the majority of the public are subject to recycling policies, it is argued that facets of a policy plays a significant role in determining the level of policy support (Jagers, Matti, \& Nilsson, 2017) that is worthy of further examination.

The aim of the current study is to comprehend the driving forces of policy support and gain better understanding of political side of influence on policy support. To this end, we first systematically identify a set of psychological and political factors influencing policy support for recycling instruments. A conceptual model integrating identified factors is developed. The model enables us to test and compare the effects of psychological and political factors on the level of policy support. The study makes conceptual and practical contributions as follows. First, unlike traditional studies which investigated the concept from the psychological perspective, this study offers a fresh angle, i.e., policy features and political environment (or political factors as a general term throughout the paper) to examine individuals' levels of policy support. Second, to authors' best knowledge, this is the first empirical study attempts to systematically integrating both psychological and political factors into a single conceptual model for analysis of policy support. The construction enables us to compare effects of two distinguished set of driving forces, which is expected to advance the understanding of the concept. Third, while most previous studies focused on examining policy support of environmental policy in general, this study gives special attention to recycling policy which all-round support from the public is crucial to the overall success of policy. Findings of this study would offer policy-makers a new approach of recruiting broader public support for recycling measures.

The remainder of the paper is organized as follows. Section 2 presents the logic and justification of conceptual development of this study, associated with the exploration of both psychological and political factors that may contribute to policy support. Section 3 is the methodology of the research. It includes description of study area, questionnaire design, data collection method, and procedures of statistical analysis. Descriptive findings are reported in section 4. Section 5 is discussion which consists of theoretical reflections on the concept policy support, policy implications, and limitations of the study. Conclusion section will end with a summary of the article. 


\section{Conceptual development}

\subsection{Rationale behind systematic factor identification}

Of particular interest for this paper is to advance the understanding of nature and origin underlying the phenomenon of public support for recycling policy. The practice helps us to identify potential factors of policy support systematically and form the skeleton of building a proper model for analysis. We argue that there are two dimensions working in parallel influencing the level of policy support, which should be taken as a starting point of investigation.

The core objective of most environmental policies is initiating changes in personal behavioral patterns for the purpose of protecting the environment or mitigating environmental problems (cf. Elmore, 1987; Schneider \& Ingram, 1990). Similarly, the basic assumption underlying recycling policy is manipulating behaviors of targeted individuals for attaining policy goals such as waste minimization (Steg \& Vlek, 2009; Stern, 2000, p. 409). Policy prescriptions would be the focus of attention in this connection. Individuals' psychological attributes in relation to prescribed behaviors matter to the level of policy support. Meanwhile, governments have power and authority over the public; people's behaviors are subject to public policy and they are required to comply with policy prescriptions (Schneider \& Ingram, 1990). The policy itself and situated political environment form another dimension of influence. Specifically, policy features (e.g., fairness, effectiveness, and processes of formulation) and individuals' relations with governments would cause primary concern amongst targeted populations. We argue that whether or not individuals would show support to a policy is, by and large, based on these two dimensions of the policy. By following the logic, we consider that psychological motivations towards the behaviors in question as well as policy features and relations with governments together constitute policy support. A similar argument was proposed by Wan et al. (2017) that policy support can be driven by internal motivators (e.g., psychological attributes) and external forces (e.g., policy features).

We label factors derived from these two dimensions influencing policy support as psychological factors and political factors. Psychological factors deal with targeted individuals' psychological attributes and subjective evaluation towards policy prescriptions. For example, attitude is a typical psychological indicator that may influence individuals' evaluation of prescribed behaviors and in turn the level of policy support. Political factors include policy characteristics and individuals' relations with governments; examples are fairness of a policy and degree of public participation provided during policy formulation processes. The quality of political factors is largely determined by governments' overall practices and performance. The rest of Section 2 provides elaboration and justification of these two driving forces of policy support, accompanying with identification of two distinguished set of variables derived from them.

\subsection{Policy support as a basket of psychological attributes}

Most environmental problems are caused by environmentally harmful human activities (Steg \& Vlek, 2009). Objectives of recycling policy are based on the assumption that personal behavioral patterns could be changed as a result that would benefit the environment (Costanzo, Dane, Elliot, \& Pettigrew, 1986; Steg \& Vlek, 2009). Therefore, one of the policy goals of recycling measures is to enhance public participation in recycling programs and to induce environmentally-benefited behaviors. An individual makes changes in behavioral 
patterns according to policy prescriptions is considered as policy support. It is because he/she makes a respond to the call of policy objectives. Therefore, internal motivations that trigger behavioral changes in recycling practices would be the focal point of investigation. In this regard, psychological variables for pro-environmental behaviors prediction provide a rich source examining the formation of public support for recycling policy. They are variables relate to individuals' perceptions towards the behaviors in question (Barr, 2007), and they have been widely adopted for human behavior explanation and model construction. According to Vining and Ebreo (1992) and Stern (1992), psychological variables are more superior to other variables such as demographic factors in predicting recycling behaviors. In the present study, five psychological factors closely associate with recycling behaviors were identified, namely, attitude, social influences, perceived benefits, past behavior, and place attachment.

\subsubsection{Attitude}

Attitude serves as a compass indicating an individual's subjective evaluation of an object (Fishbein \& Ajzen, 1975). An individual's degree of favor towards an object has significant predictive power for behavioral intention and behaviors (Ajzen, 1991). A large number of studies demonstrated a positive link between specific attitude and pro-environmental activities (e.g., Chan, 1998; Chen \& Tung, 2010; Cheung, Chan, \& Wong, 1999; Tonglet, Phillips, \& Bates, 2004; Valle, Rebelo, Reis, \& Menezes, 2005). Eagly and Chaiken (1992) explained that people possessing positive attitude would result in engagement in behavior that approach, support, or enhance the attitude object. Similarly, Gifford and Sussman (2012) proposed that the predictive power of environmental attitude for individual behavior (e.g., recycling) could be extended to prediction of other similar behaviors (e.g., support political decisions). Empirically, Wan et al. (2015) proved that recycling attitude is positively correlated to policy support for measures such as waste charging scheme. Therefore, it is proposed that specific attitude, i.e., recycling attitude, is positively correlated to the level of policy support.

\subsubsection{Social influences}

Another source shaping our behaviors is influences from the society. Ajzen and Fishbein (1980) termed one of the influences from the society as subjective norm, and argued that an individual's perceptions of important others (e.g., friends and family members) of performing a behavior determine his/her behaviors. Subjective norm shares a large similarity with the

concept injunctive norm proposed by Cialdini, Kallgren, and Reno (1991), which stated that an individual's behaviors are linked to what other people think it should be done in a specific context. People tend to participate in behaviors (e.g., Cheung et al., 1999; Valle et al., 2005; Vining \& Ebreo, 1992) or support behaviors (e.g., Bamberg \& Rölle, 2003; Jakobsson, Fujii, \& Gärling, 2000) that are commonly done or approved by their significant others. In a broader sense, our behaviors are guided and governed by a set of agreed standards and norms in the society (Cialdini \& Trost, 1998). To seek social approval, we adhere to the ways that the society expects us to behave in a particular situation. Therefore, other than significant others, our behaviors are shaped by various sources of influences from the society. For example, Fielding, McDonald, and Louis (2008) pointed out that environmental groups exert their influences over the public by advocating environmental issues through different channels, such as promotional campaigns. Chan (1998) also found that mass media is another source of social influences that positively correlates to participation of environmental behaviors. Clearly, social influences can be a key factor explaining policy acceptability. 


\subsubsection{Perceived benefits}

Performing a behavior entails costs and benefits. According to the assumption of rationality, costs and benefits of performing a behavior is a matter of concern to individuals when making reasoned decisions (Steg \& Vlek, 2009; Stern, 1992). The term perceived benefits is defined as expected positive consequences of performing a behavior (Davies, Foxall, \& Pallister, 2002). An increasing willingness to engage in prescribed behaviors appears to be positively associated with perceived net benefits of a policy. For instance, respondents' perceived consequences of recycling behaviors (e.g., recycling saves money and energy) was proved to be a significant predictor of frequency of household recycling (Tonglet et al., 2004). In a similar vein, Tobler et al. (2012) found that perceived benefits is a prominent determinant of support to policies addressing climate change. Wan et al. (2015) also revealed a remarkable positive effect of perceived benefits on support level of capacity-building waste management policies such as publicity work for promoting recycling. Based on the argument and empirical results found in existing literature, this study also investigates the role of perceived benefits in determining the level of public support for recycling policies. The greater awareness of net benefits associated with a policy, the higher level the individual would support the policy instrument.

\subsubsection{Past behavior}

Individuals who have previously involved in a behavior may have clarified misunderstanding of a behavior and lowered their resistance to perform that behavior (Dahab, Gentry, \& Su, 1995). The likelihood of participating in the behavior again would be higher. Barr (2007) described the process as a behavioral snowball effect which similar behaviors may be taken as a result of previous experience. Concerning the recycling behavior, prior recycling experience has been documented as a superior predictor of future recycling behavior in empirical studies such as Boldero (1995), Cheung et al. (1999), Knussen, Yule, MacKenzie, and Wells (2004), and Lee, De Young, and Marans (1995). The role of past behavior in explaining future behavior can also be justified provided that the behavior in question is repetitively carried out, for instance, recycling practices (Smith, Terry, Manstead, \& Louis, 2007). The repeated works (e.g., engaging the same set of recycling procedures daily or weekly) can be considered as a habitual behavior which an individual tends to perform the course of actions that are less likely to be based upon individuals' consciousness (Knussen et al., 2004; Ouellette \& Wood, 1998). Overall, it is expected that people who have experience of waste recovery are more likely to continue the practices and support related policies.

\subsubsection{Place attachment}

Place attachment has been increasingly proved as a predictor of pro-environmental behaviors. The concept can be broadly defined as affective bonds established between individuals and specific social or physical settings (Giuliani, 2003; Hidalgo \& Hernández, 2001; Low \& Altman, 1992). It is argued that an individual who possesses a strong sense place attachment would incline to protect the environment of the place and hence increase the likelihood of taking place-protective actions. Scannell and Gifford (2010) labeled such actions induced by the cultivated bonds of attachment to a specific place as a proximity-maintaining behavior. Several studies empirically proved that pro-environmental behaviors are associated with place attachment (Brehm, Eisenhauer, \& Krannich, 2006; Scannell \& Gifford, 2010; Vaske \& Kobrin, 2001; Vorkinn \& Riese, 2001). By following the argument of these studies, the 
present study posits that place attachment can also significantly explain acceptance of or support for recycling policy, a behavior which protects and benefits the environment.

Based on above literature on socio-psychological aspect of policy support, the following hypotheses are proposed:

H1: Attitude (ATTD) positively influences the level of policy support.

H2: $\quad$ Social influences (SI) positively influences the level of policy support.

H3: $\quad$ Perceived benefits (PB) positively influences the level of policy support.

H4: $\quad$ Past behavior (PBEV) positively influences the level of policy support.

H5: $\quad$ Place attachment (PA) positively influences the level of policy support.

\subsection{Policy factors: a hidden dimension for policy support}

Another source shaping the public support for recycling policy is fundamentally linked to policy characteristics and the associated political environment. Public policy has power over individuals' behaviors; it constrains and governs behaviors of targeted populations (Schneider \& Ingram, 1990). Subject to the power of public policy, targeted individuals would pay considerable attention to policy features such as policy effectiveness and fairness. Assessment of the policy becomes a major determinant of policy support (Coombs, 1980). The argument is supported by a growing number of studies that attributed the phenomenon of policy support for environmental programs to policy characteristics and associated political environment. For example, Lee et al. (2013) noticed that by engaging the public in recycling policy decision-making processes would enhance transparency, making the policy more acceptable to the public. Keramitsoglou and Tsagarakis (2013) empirically proved that trust in institutions is the basic ingredient of public acceptance of recycling schemes. Fairness of a policy is generally recognized as a factor promoting public support (de Groot \& Schuitema, 2012). This line of literature calls into question the predictive adequacy of prevalent behavior models developed in the field of environmental psychology and social psychology. In this connection, Wan and his colleagues (2017) conducted a systematic review on political factors that may influence the level of policy support for urban environmental policy. The study found that $25 \%$ of their sampled articles discussed policy support in relation to policy features. Based on the finding, they considered political factors as an independent block that influences policy support along with psychological and demographic factors. We therefore suggest that policy characteristics and political environment may associate with the level of policy support. Five political factors were extracted from the literature and discussed below.

\subsubsection{Perceived policy effectiveness}

Every public policy is associated with specific goals. For instance, recycling policy is proposed with objectives of waste minimization and increasing recovery rate. Whether or not the proposed policy is effective in goal attainment would be important for governments to convince the public to support the policy. People would not see the point of supporting the policy if it has no effect on achieving policy objectives. Lubell (2003) defined individuals' beliefs in the capability of public policies that are likely to result in intended outcomes as perceived policy effectiveness. An effective policy increases the attractiveness of taking prescribed actions (Steg \& Vlek, 2009). Wan, Shen, and Yu (2014) highlighted the tangible impact of perceived policy effectiveness on participation of recycling activities. Many other studies which investigated acceptance of different types of policy also shared the view that individuals are prone to show their support if they perceived that the proposed policy and 
measures are effective for goal attainment (e.g., Eriksson, Garvill, \& Nordlund, 2008; Jagers et al., 2017; Wan et al., 2015). Therefore, this study posits that perceived policy effectiveness would make significant independent contribution to the variance in policy support.

\subsubsection{Political trust}

A high level of political trust among the public can easily engender agreement on policy that aims at addressing environmental problems (Konisky, Milyo, \& Richardson, 2008). Political trust refers to individuals' confidence in the government that it will achieve outcomes that are consistent with their expectations (Easton, 1975; Hetherington, 2005). It plays a significant role in alleviating the public's doubts about the newly introduced environmental policies. Findings by Harring and Jagers (2013) and Kollmann and Reichl (2015) revealed that individuals possessing a high level of political trust entails that they have confidence in authorities' capability to tackle environmental problems with an effective and responsible manner. This group of people is more willing to support environmental policies, such as the introduction of new environmental taxes. The significant influence of political trust on the level of policy support was verified in studies investigating willingness to pay for environmental protection (e.g., Kollmann \& Reichl, 2015), compliance with environmental regulations (Zannakis, Wallin, \& Johansson, 2015), and willingness to make economic sacrifices for environmental protection (e.g., Harring, 2013; Kyselá, 2015).

\subsubsection{Fairness}

Many environmental policies are directed towards individuals. According to Clayton (1998, 2000), individuals attach great importance to policy fairness and the concept has been linked to individuals' acceptance of and support for environmental policies. Specifically, people pay attention to both procedural fairness and distributive fairness of a policy. Procedural fairness is conceptualized as policy formulation processes which involved parties are treated consistently and respectively, and there are sufficient representativeness and opportunities for opinion expression (Tyler, 1990). With regard to distributive fairness, it refers to policy outcomes that every targeted individual shoulders costs and responsibility by fair principles (Tyler, 2000). Kals and Russell (2001) labeled the two concepts with the term perceived justice and argued that it is a factor determining an individual's willingness to act proenvironmentally and the level of policy support. Empirical evidence confirmed that the greater satisfaction of policy fairness, the more willing that an individual would support authorities' decisions on environmental problems, such as earmarking more spending on environmental protection (Rasinski, Smith, \& Zuckerbraun, 1994), introduction of environmental taxations (Kim, Schmöcker, Fujii, \& Noland, 2013), building waste management facilities (Lima, 2006; Rahardyan, Matsuto, Kakuta, \& Tanaka, 2004), and mandatory recycling policies (Ohnuma, Hirose, Karasawa, Yorifuji, \& Sugiura, 2005).

\subsubsection{Participatory process}

An extensive literature took public participation as a promising tool to recruit public support (e.g., Daley, 2013; Garneet \& Cooper, 2014; Petts, 2001; Reed, 2008). Engaging the public at early stage of policy formulation processes ensures that a wide range of stakeholders' perspectives could be captured (Luyet, Schlaepfer, Parlange, \& Alexandre, 2012). Taking public concerns at early stage is also a part of policy decisions and it facilitates formulation of responsive policies (Innes \& Booher, 2004). According to Beierle and Konisky (2000) and Petts (2000), participatory process offers opportunities of policy deliberation to the public 
and ensures that collected public opinions and suggestions would be given close attention. Though participatory process, the public can access to more background information of proposed initiatives and they would have in-depth discussions with policy-makers and technical experts. The process engenders a greater common understanding of different parties' values while clarifies doubts about the policy issue (Garneet \& Cooper, 2014; Renn, 2006). Incorporating public values and suggestions to policy decisions can grow a sense of empowerment among the public (Reed, 2008); the practice also enhances the development of holistic solutions to environmental problems (Lee et al., 2013; Reed, 2008). According the literature, all mentioned participatory processes can improve transparency of decision-making and legitimacy of the policy, which form a foundation of accumulating public support. Policy support will be enhanced by offering more participatory decision-making activities to the public.

\subsubsection{Policy preference}

Policy preference registers support for government actions (Jennings \& Wlezien, 2015). It refers to public preference for authorities' priority to address a particular problem over others (Konisky et al., 2008, p. 1081; Page \& Shapiro, 2010; Wlezien, 1995). There are different types of environmental issue such as waste management, air pollution, and biodiversity degradation. Authorities may accord some environmental issues low priority in the competition for scarce resources. As a result, preference across issues may be different between the official agenda and the public expectation. Shared the view with Kingdon (1995), it is argued that an appropriate time for policy initiation, that is, a policy window, is critically important to the success of policy implementation. Moreover, opinions on resources investment and instrument selection for addressing the environmental problem in question may be different between authorities and the public. Altogether, there is greater chance of creating a policy preference gap (Daniels, Krosnick, Tichy, \& Tompson, 2013) and the initiated policy may end with insufficient public support. In addition, the public's policy preference is subject to advocacy and political climate (Wan \& Shen, 2013). Though not much empirical research has been undertaken, it is argued that policy preference can be considered as a reliable predictor of policy support. Policy decisions which show congruence with public preference would return significant improvement of policy support.

Based on above discussion, five additional hypotheses are formed:

H6: $\quad$ Perceived policy effectiveness (PPE) positively influences the level of policy support.

H7: $\quad$ Political trust (T) positively influences the level of policy support.

H8: $\quad$ Fairness (FAIR) positively influences the level of policy support.

H9: $\quad$ Policy preference (PPRE) positively influences the level of policy support.

H10: Participatory process (PP) positively influences the level of policy support.

Figure 1 presents the conceptual model of policy support for recycling policy. The literature review suggests that the source of policy support derives from both psychological attributes and political aspects of a policy. Following the logic of the argument, the key to the model is the conceptualization of policy support as individuals' perceptions towards policy prescriptions and the assessment of both the policy itself and political environment. The two building blocks represent psychological evaluation and political facets of recycling policy, respectively; and lay the foundation of policy support. 


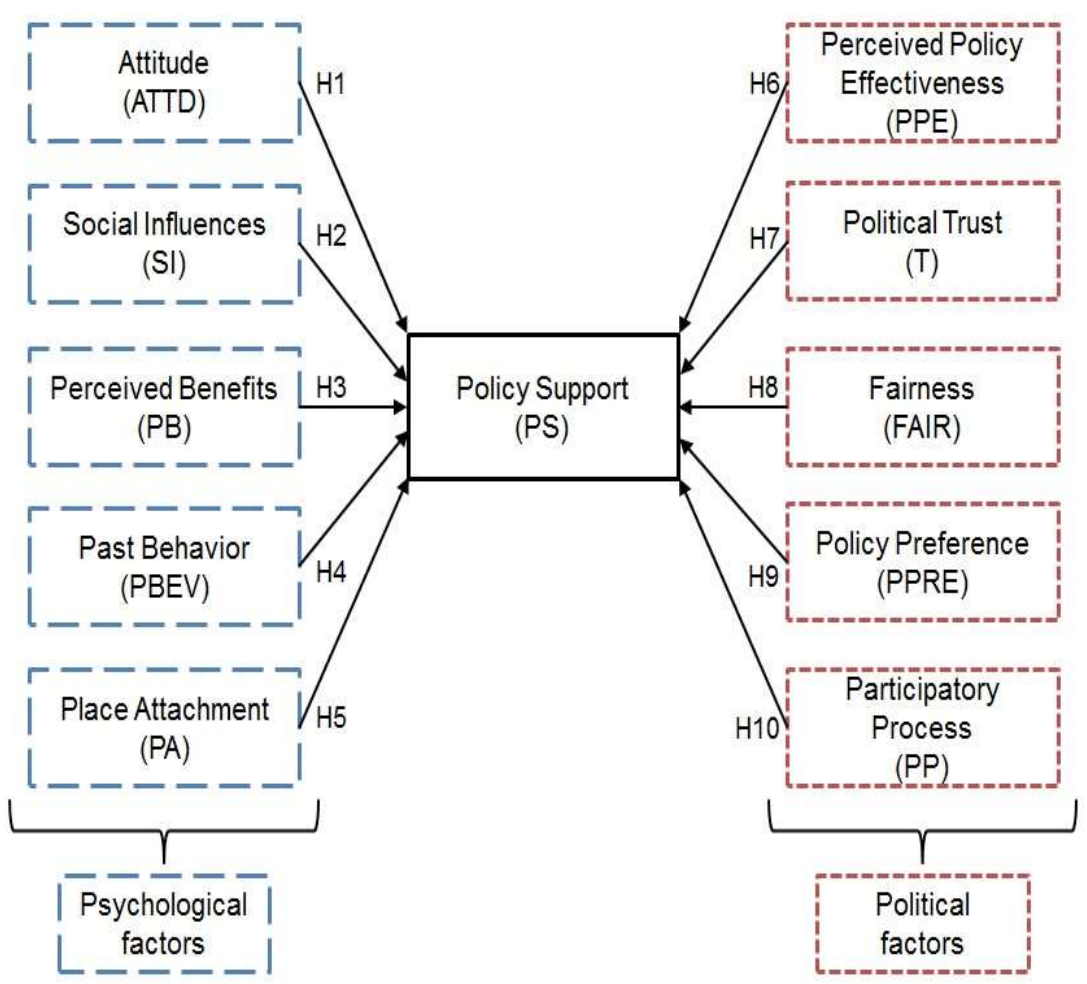

Figure 1 The conceptual model of policy support for recycling policy

\section{Methodology}

\subsection{Study area}

The study was conducted in Hong Kong. The city has a terrestrial area of $1,105 \mathrm{~km}^{2}$ and a resident population of around 7.3 million. Hong Kong has long been relying heavily on landfilling for waste disposal, making waste management a pressing environmental issue in the densely populated city. Though the government was used to introduce sustainable waste management measures to mitigate the problem, most policies or initiatives had suffered setbacks and little progress had been made as a result. For example, the Municipal Solid Waste Charging Scheme had been discussed for over 25 years but opinions of what makes as a fair charging mode are still found to be divergent and consensus has not been reached (Cheung, 2013; SCMP Editorial, 2014). Volume of waste disposal remains on the rise (Environmental Protection Department, 2017). Given that landfills in Hong Kong will reach full capacity late this decade, waste management with the principle of sustainability has been emphasized. Policy support and active participation from the public would be vital to successful policy implementation and goal attainment. Therefore, Hong Kong is an ideal case of studying public support for recycling policy.

\subsection{Questionnaire design}

A questionnaire with ten independent variables and one dependent variable was developed to probe respondents' opinion. All independent variables are factors identified in Section 2. The first part of the questionnaire consisted of five psychological variables that measure various psychological attributes of respondents, namely, attitude, social influences, perceived benefits, 
past behavior, and place attachment. Indicators of these variables (i.e., questionnaire items) were developed with reference to studies by Hidalgo and Hernández (2001), Sidique, Lupi, and Joshi (2010), Tonglet et al. (2004), Tonglet et al. (2004), and Wan et al. (2014, 2015). To investigate effects of policy characteristics and political environment on policy support, another set of independent variables including perceived policy effectiveness, political trust, fairness, policy preference, and participatory process were constructed by drawing reference to various prior studies, including Daniels et al. (2013), Garneet and Cooper (2014), Hetherington (2005), Kim et al. (2013), Konisky et al. (2008), Ohnuma et al. (2005), and Wan et al. (2014). The scale with multiple items can establish reliability and validity of the variables while single-item measure for human behavior variable usually returns unacceptably low reliability (Bergkvist \& Rossiter, 2007; Wanous, Reichers, \& Hudy, 1997). Thus, multiple items (i.e., questionnaire items) instead of single-item measures for each variable were developed in this study. Besides, since most studies drawn for questions development were not conducted in Hong Kong, we have made necessary changes to wordings of questionnaire statements to suit the context of Hong Kong, for example, replacing policy names that are specific to the case of Hong Kong.

The third section of the questionnaire was the dependent variable policy support. It was assessed by eight constructed statements drawn from current and proposed waste management policies in Hong Kong (Environmental Protection Department, 2016). All statements were used to gauge respondents' support level to various recycling policies. Respondents were asked to rate their level of agreement to all indicators based on a sevenpoint Likert scale, ranging from 1 (strongly disagree) to 7 (strongly agree). The scale is one of the most widely adopted rating scales of measuring attitudes in quantitative research. Given that this research intends to assess respondents' levels of policy support, strength of behaviors/attitudes, and evaluation of outcomes, thus, Likert scale is considered as an appropriate rating scale. The final section of the questionnaire was socio-demographic items. Age, gender, education level, and monthly income were measured in this part. Details of questionnaire items are given in Appendix A.

\subsection{Data collection}

The dataset was collected using a random household telephone survey. This method is able to provide satisfactory response rate and offers opportunities to both interviewers and respondents for clarifying questions and answers (Hine, Kormos, \& Marks, 2016). The fieldwork was conducted at 6:30 pm to 10:30 pm every day between July and August 2016 . Using the prefixes assigned to residential telephone lines by the local telecommunication authority, telephone numbers were randomly generated by the computer system. Invalid numbers were subsequently removed based on the past dialing records. Cantonese-speaking Hong Kong residents from aged 18 to 65 were targeted for an interview. Last birthday selection method was used if there were more than one eligible respondent in a household. A total of 504 respondents were successfully interviewed, with a response rate of $76.1 \%$. The sample characteristics are shown in Table 1.

\subsection{Statistical analysis}

Structural equation modeling (SEM) was chosen for statistical analysis in this study. It measures relationship among unobservable latent variables (Chin, 1998; Jöreskog \& Sörbom, 1989) and enables researchers to evaluate the unique effect of each variable. SEM is preferred over other statistical methods because it is suggested to be suitable for studies 
which contain unobservable latent variables that are difficult to measure directly (Chin, 1998; Wong, 2013). There are two dominant statistical approaches for assessing structural equation models, namely, covariance-based approach (CB-SEM) and variance-based partial least squares approach (PLS-SEM) (Hair, Hult, Ringle, \& Sarstedt, 2013). PLS-SEM has a competitive advantage over CB-SEM in theoretical model development and in study which seeks to explore causal relationships between latent variables (Hair, Ringle, \& Sarstedt, 2011). Given that the key objective of the current study focuses on explaining policy support by proposed constructs, and attempts to develop an integrated framework for optimizing explanations of policy support, PLS-SEM is deemed to be more suitable for this study. The statistical software application SmartPLS 3.0 (Ringle, Wende, \& Becker, 2015) was employed to measure the conceptual model developed in this study.

\section{Findings}

\subsection{Respondent profile}

A total of 504 valid responses (i.e., successfully interviewed cases) were collected from the telephone survey. According to the guideline proposed Hair et al. (2011), the minimum sample size for PLS analysis should be 10 times the largest number of hypothesized relationships directed to a dependent construct. In this study there are 10 paths pointing at the dependent construct policy support; thus, the minimum required observations would be $10 \times$ 10 , which corresponds to 100 . Therefore, the sample size of 504 is statistically sufficient for analysis.

Table 1 gives a summary of respondents' socio-economic characteristics, with corresponding comparison of the 2011 Hong Kong Population Census. The sample appears to be roughly representative of the general population, with the exception of sub-category of education level and monthly income level. Comparing with the census data, the sample may slightly overstate the views of individuals with Bachelor's degree while people with monthly income between HK\$10,000 and HK\$19,999 may be underrepresented. Besides, some respondents were not willing to disclose their demographic information; hence, the sub-category "missing" was used to label missing value of demographic information (i.e., age, education level, or monthly income). 
Table 1 Comparison of respondent profile with 2011 Hong Kong Population Census

\begin{tabular}{|c|c|c|c|}
\hline Demographic Variable & Sample (N) & Sample (\%) & Census (\%) \\
\hline \multicolumn{4}{|l|}{ Gender } \\
\hline Female & 290 & 57.54 & 51.94 \\
\hline Male & 214 & 42.46 & 48.06 \\
\hline \multicolumn{4}{|l|}{ Age group } \\
\hline $18-29$ & 101 & 20.04 & 22.19 \\
\hline $30-39$ & 62 & 12.30 & 20.64 \\
\hline $40-49$ & 115 & 22.82 & 24.23 \\
\hline $50-59$ & 134 & 26.59 & 23.44 \\
\hline $60-65$ & 78 & 15.48 & 9.51 \\
\hline Missing & 14 & 2.78 & N/A \\
\hline \multicolumn{4}{|l|}{ Education Level } \\
\hline Primary or below & 39 & 7.74 & 16.68 \\
\hline Secondary & 220 & 43.65 & 50.27 \\
\hline Sub-Degree & 46 & 9.13 & 10.36 \\
\hline Bachelor's Degree & 152 & 30.16 & 16.51 \\
\hline Master's Degree or above & 39 & 7.74 & 6.17 \\
\hline Missing & 8 & 1.59 & N/A \\
\hline \multicolumn{4}{|l|}{ Monthly Income (HK\$) } \\
\hline Below 10,000 & 167 & 33.13 & 39.56 \\
\hline $10,000-19,999$ & 111 & 22.02 & 33.15 \\
\hline $20,000-29,999$ & 77 & 15.28 & 12.10 \\
\hline $30,000-39,999$ & 32 & 6.35 & 6.12 \\
\hline 40,000 or above & 69 & 13.69 & 9.08 \\
\hline Not stable & 10 & 1.98 & N/A \\
\hline Missing & 38 & 7.54 & N/A \\
\hline
\end{tabular}

Source: Census and Statistics Department, HKSAR (2011)

\subsection{Measurement Model}

PLS analysis involves two steps, namely assessment of measurement model and assessment of structural model (Chin, 1998; Hair et al., 2011). The measurement model focuses on examining reliability and validity of indicators of the constructs. Composite reliability, convergent validity, and discriminant validity of each construct would be evaluated in this study. Both composition reliability and convergent validity are used to investigate relationships among indicators within the same construct that should possess a high correlation with one another. Chin (1998) and Fornell and Larcker (1981) recommended the following threshold values for evaluating measurement scales, (i) Factor loadings for indicators of a construct should be significant and exceed 0.5; (ii) Average variance extracted (AVE) of each construct should higher than 0.5; (iii) Composite reliability of a construct should exceed 0.7. As shown in Appendix B, all indicators and constructs fulfill the statistical criteria recommended.

The discriminant validity refers to that indicators of a construct are unique and distinct from indicators of other constructs (Campbell \& Fiske, 1959). To assess discriminant validity, a 
construct's square root of AVE value should exceed the correlations between that construct and any other construct in the model (Chin, 1998; Fornell \& Larcker, 1981). Appendix C shows that all constructs meet the requirement which implies that these constructs are independent of each other.

\subsection{Structural Model}

The second step of PLS analysis is structural model assessment. Statistical significance of the hypothesized relationships in the proposed model would be examined (Hair et al., 2011). To determine the level of statistical significance, the model was analyzed by using a bootstrap resampling routine with cases (surveyed responses) and 5,000 subsamples. The bootstrap resampling routine assesses the significant level of the casual relationship specified in the model that subsamples are generated by randomly selecting a case from the dataset (Chin, 1998). Coefficients $(\beta)$ and $t$-statistics of each hypothesized relationship determine the strength of impact and level of significance respectively. $R$-square $\left(R^{2}\right)$ value represents the variance percentage of a dependent construct that can be explained by the independent constructs, a value of $0.25,0.50$, and 0.75 can be interpreted as weak, moderate, and substantial explanatory power, respectively (Hair et al., 2013).

\subsubsection{The impact of psychological and political factors on policy support}

The findings lend support to most of our research hypotheses $(\mathrm{H} 1, \mathrm{H} 3, \mathrm{H} 6, \mathrm{H} 8, \mathrm{H} 9$, and $\mathrm{H} 10$ were supported; Table 2). Two psychological constructs were noticeable in predicting the level of policy support. The hypothesis H1 was supported $(\beta=0.181, t=4.806, p<0.001)$. Attitude was the second most important psychological factor influencing the level of policy support in the psychological model (Table 3). Similar to other types of pro-environmental behavior, public support for recycling policy can be framed as attitude-driven. Attitude predicting recycling behavior may also predict other similar behaviors or support level of environmental decisions (Daneshvary, Daneshvary, \& Schwer, 1998; Gifford \& Sussman, 2012), the present study suggests that an individual's attitude toward recycling is a remarkable predictor of policy support for recycling policy.

The hypothesized relationship between perceived benefits and policy support was significant (H3, $\beta=0.285, t=7.599, p<0.001)$. Perceived benefits possessed the largest proportion of explained variance compared with other psychological constructs, contributing about $25 \%$ to the $R^{2}$ value (Table 3 ). It appears that respondents take costs and benefits of performing recycling behaviors as their prioritized considerations. Individuals are more likely to support a policy and willing to take prescribed course of actions if they found it rewarding and worthwhile. The finding gives additional evidence to previous studies such as by Davies et al. (2002), Valle et al. (2005) and Wan et al. (2015).

As for the political factors, four constructs showed a significant effect on the level of policy support. Perceived policy effectiveness demonstrated as a remarkable driver of policy support (H6, $\beta=0.087, t=2.109, p<0.05$ ). A supportable policy environment facilitates recruitment of public support. Take recycling policy as an example. The availability of facilities and information promote recovery and recycling behaviors, as well as boost the confident of an individual in effective policy goal attainment. Overall, a policy which is perceived as highly effective is proved to be a guarantee of extensive public support. 
The positive relation between fairness and the level of policy support was established (H8, $\beta$ $=0.222, t=4.361, p<0.001)$. Both procedural and distributive fairness are salient features of public support for recycling policy. Individuals who feel that a policy is formulated with fair procedures and that the costs of performing prescribed actions or policy outcomes are justly shared among targeted populations are more likely to support the policy. Fairness of policy decision-making processes and policy outcomes is a precondition of gaining public support for recycling policy.

The link between policy preference and level of policy support was strong ( $\mathrm{H} 9, \beta=0.371, t=$ $9.260, p<0.001)$. Among four significant political factors, policy preference accounted for $33.5 \%$ of the variance in policy support (Table 3). An individual's inclination to support the recycling policy is, by and large, driven by the extent to which the proposed initiative matches the public preference. Empirical evidence suggested that the more the policy is responsive to the public preference, the more the public would incline to support the policy. Therefore, addressing the public concerns in a timely manner with appropriate policy instruments has an essential importance for gaining policy support (Wan \& Shen, 2013; Wlezien, 1995).

An unexpected negative path relationship between participatory process and policy support was found $(\mathrm{H} 10, \beta=-0.122, t=2.602, p<0.01)$. In view of this, bivariate relationship between the factor and policy support was tested. The result showed a positive significant relationship $(\beta=0.273, t=7.293, p<0.001)$. We suggested that the negative relationship may be a statistical artifact when a large number of casual relationships were included in the model. In regardless of the unexpected statistical result found, it is believed that participatory process is a driver of policy support provided that the argument is supported by substantial literature. Studies have proposed that engaging the public and to provide people with opportunities expressing viewpoints and incorporating suggestions into final decisions would improve transparency of decision-making and, in turn, contribute to the formation of policy support (e.g., Daley, 2013; Garneet \& Cooper, 2014; Lee et al., 2013; Luyet et al., 2012; Petts, 2000, 2001; Reed, 2008; Renn, 2006). Therefore, participatory process can still be regarded as a remarkable contributor to policy support.

Contrary to our expectation, the constructs social influences (H2), past behavior (H4), place attachment (H5), and political trust (H7) bore little relation to the level of policy support (Table 2). The insignificant effect of social influences on policy support may due to the unique residential setting in Hong Kong. The apartment houses dominated residential environment implies that individuals' behaviors such as recycling practices, are subject to less scrutiny from the neighbors and important others (cf. Boldero, 1995). Effects of social influences on motivating recycling behaviors would be largely reduced, making it as an unimportant factor. Prior studies measured the effects of past recycling experience on future recycling behavior (a direct pro-environmental behavior) (e.g., Boldero, 1995; Cheung et al., 1999). In the present study, however, past recycling experience was used for assessing the level of policy support, that is, an indirect pro-environmental behavior. The one-to-one direct relationship as hypothesized may not be established as a result. The apolitical society may explain the weak relationship established between political trust and policy support. Hong Kong citizens have long been recognized as indifferent to government operations and politics (Cheng, 2014). The political culture probably affects the assessment of government performance and thus results in the insignificant relation of two variables in the Hong Kong context. As for the place attachment, its significant performance in psychological model may 
be overtaken by those newly acceding political factors, resulting as an unimportant factor in the integrated model.

Table 2 Psychological Model vs. Integrated Model

\begin{tabular}{|c|c|c|c|c|c|c|}
\hline \multirow{2}{*}{ Construct } & \multicolumn{3}{|c|}{ Psychological Model } & \multicolumn{3}{|c|}{ Integrated Model } \\
\hline & $\beta$ & $t$-Value & Sig. & $\beta$ & $t$-Value & Sig. \\
\hline H1: Attitude (ATTD) & 0.257 & 5.459 & $* * *$ & 0.181 & 4.806 & $* * *$ \\
\hline H2: Social influences (SI) & 0.051 & 1.295 & & -0.047 & 1.265 & \\
\hline H3: Perceived benefits (PB) & 0.391 & 8.661 & $* * *$ & 0.285 & 7.599 & $* * *$ \\
\hline H4: Past behavior (PBEV) & 0.068 & 1.584 & & 0.051 & 1.433 & \\
\hline H5: Place attachment (PA) & 0.114 & 3.222 & $* * *$ & 0.004 & 0.096 & \\
\hline H6: Perceived policy effectiveness (PPE) & & & & 0.087 & 2.109 & $*$ \\
\hline H7: Political trust $(\mathrm{T})$ & & & & 0.017 & 0.422 & \\
\hline H8: Fairness (FAIR) & & & & 0.222 & 4.361 & $* * *$ \\
\hline H9: Policy preference (PPRE) & & & & 0.371 & 9.260 & $* * *$ \\
\hline H10: Participatory process (PP) & & & & -0.122 & 2.602 & $* *$ \\
\hline $\begin{array}{l}R^{2} \\
f^{2} \\
\end{array}$ & & 0.433 & & & $\begin{array}{l}0.587 \\
0.373 \\
\end{array}$ & \\
\hline
\end{tabular}

Table 3 Explanation of variance $\left(R^{2}\right)$

\begin{tabular}{|c|c|c|c|}
\hline Variable & $\beta$ & $r$ & Contribution to $R^{2}$ \\
\hline Attitude (ATTD) $)^{\#}$ & 0.181 & 0.518 & $13.869 \%$ \\
\hline Social influences (SI) & -0.047 & 0.311 & $2.162 \%$ \\
\hline Perceived benefits $(\mathrm{PB})^{\#}$ & 0.285 & 0.595 & $25.085 \%$ \\
\hline Past behavior (PBEV) & 0.051 & 0.333 & $2.512 \%$ \\
\hline Place attachment (PA) & 0.004 & 0.245 & $0.145 \%$ \\
\hline Perceived policy effectiveness (PPE) & 0.087 & 0.304 & $3.912 \%$ \\
\hline Political trust $(\mathrm{T})$ & 0.017 & 0.188 & $0.473 \%$ \\
\hline Fairness (FAIR) & 0.222 & 0.424 & $13.924 \%$ \\
\hline Policy preference (PPRE) $)^{\#}$ & 0.371 & 0.611 & $33.532 \%$ \\
\hline Participatory process $(\mathrm{PP})^{\#}$ & -0.122 & 0.243 & $4.385 \%$ \\
\hline
\end{tabular}

${ }^{\#}$ significant variable in the explanation of policy support

\subsubsection{Model significance}

Table 2 summarizes the results of the structural model assessment. In the psychological model, five constructs (i.e., attitude, social influences, perceived benefits, past behavior, and place attachment) together explained $43.3 \%$ of the variance in policy support. By adding political constructs and forming an integrated model, the $R^{2}$ value increased to $58.7 \%$, with attitude and perceived benefits retained their significant predictive utility while the newly added political constructs, i.e., perceived policy effectiveness, fairness, policy preference, and participatory process, were statistically significant. In order to evaluate the effect of political constructs on policy support, Cohen (1988) suggested using a formula that is based on the $R^{2}$ value with the proposed predictors included and excluded from the model: $f^{2}=\left(R^{2}\right.$ incl $\left.-R_{\text {excl }}^{2}\right)$ / $\left(1-R^{2}\right.$ incl $)$. Values of $0.02,0.15$, and 0.35 can be read as small, medium, and large effects, respectively. The effect size of political constructs on policy support in this study was 0.37 , 
which denoted a large effect. The identified political constructs play a key role shaping public support for recycling policy in the Hong Kong context.

To examine the extent to which each factor's contribution to the predictability of policy support, we divided the $R^{2}$ value in terms of the multiple regression coefficients and correlations between the dependent variable and the independent ones (Tenenhaus, Vinzi, Chatelin, \& Lauro, 2005). Table 3 shows that policy preference is the most important variable in explaining policy support, contributing to nearly $34 \%$ of the $R^{2}$ value, followed by perceived benefits $(25.1 \%)$, fairness $(13.9 \%)$, attitude $(13.9 \%)$, participatory process $(4.4 \%)$, and perceived policy effectiveness $(3.9 \%)$. The rest independent variables (i.e., social influences, past behavior, place attachment, and political trust) were not significant in determining policy support since each variable only contributed less than $3 \%$ of the $R^{2}$ value. The four significant political factors collectively contributed over half of the $R^{2}$ value (about $55 \%$ ) of the integrated model, which was greater than the percentage generated by the remarkable psychological constructs (about 39\%).

\section{Discussion}

\subsection{Reflections on policy support}

Reflections on the concept of policy support were made. The research advances our conceptual understanding of policy support for waste management policies. Policy support for environmental instruments has been considered as an environmental behavior (Stern, 2000). Traditional literature mostly took social psychological explanations for policy support (e.g., Rauwald \& Moore, 2002; Steg et al., 2005). As a result of the conceptual bias, the current literature overlooks the fact that policy support may also be influenced by facets of a policy. The present study fills in the gap in policy support literature. By adding identified political factors into the conceptual model which is built with psychological constructs only, predictability of the integrated model improved remarkably which the explained variance in policy support increased from $44 \%$ to $58 \%$ (Table 2); and most political factors were significant in predicting policy support. Notably, both psychological and political factors have predictive power for the level of policy support. Policy support should not be conceptualized as either psychological relations between targeted individuals and prescribed course of actions or a politically-driven phenomenon, but a result of both side of influence (see Wan et al., 2017).

Political factors were found to be more prominent in determining the support level of recycling policies compared to psychological attributes, with perceived policy effectiveness, fairness, policy preference, and participatory process together contributed around $55 \%$ to the $R^{2}$ value. By contrast, the two significant psychological factors, attitude and perceived benefits, contributed less than $40 \%$ to the $R^{2}$ value (Table 3 ). It is suggested that, when making decision of showing support to recycling policy, individuals would go beyond psychological considerations and pay greater attention to policy features (e.g., fairness and effectiveness of the policy) and the processes that the policy is being formulated (e.g., degree of public participation). Psychological factors such as perceptions towards policy prescriptions become less influential in this case. The fact that public policy restricts behaviors of targeted individuals may explain why more attention is given to policy features.

The statistical results bring us to another issue of which perspective should be taken as the most appropriate angle for policy support explanation (cf. Steg \& Vlek, 2009). Though a 
variety of factors were identified and proved to be significant in predicting policy support in past studies, many of the research were ad-hoc investigations (Kallbekken \& Sælen, 2011). The established relations between diversified variables and the level of policy support are not conducive to model-building and these findings may fail to include important aspects that account for policy support. In responsive to the calls from Steg and Vlek (2009) and Stern (2000) that systematic research on the range of application of different perspectives is needed, this study identified driven factors of policy support by first making understanding of nature and origins of policy support, that is the interactive results between targeted individuals and prescribed behaviors on the one hand and policy features on the other hand. Empirical evidence revealed that the suggested approach and the developed integrated model of this study had better performance in capturing comprehensive dimension of the phenomenon; they offer a solid foundation for systematically examining the concept and contribute to future research of policy support for other types of environmental policy.

\subsection{Implications for policy-making}

Findings of the present study should help policy-makers formulate appropriate recycling measures. It has been the established practice of authorities to mitigate and solve waste problems by changing individuals' behaviors, provided that most of these problems are originated from adverse human behaviors (Steg \& Vlek, 2009). Consistent with our expectation, attitude was a significant predictor of policy support. Individuals possessing favorable dispositions towards policy prescriptions were prone to support recycling policies. Therefore, eliminating negative perceptions towards the behavior in question would be at the heart of intervention strategies. Given that publicity work is the vanguard in changing individuals' attitude, it thereby takes an important role in waste management frameworks. Governments should establish a set of comprehensive and up-to-date publicity work such as education programs and informational interventions (Abrahamse \& Matthies, 2012) to build up a positive feeling about recycling behaviors and to enhance environmental awareness among the public.

Perceived benefits was another remarkable psychological construct determining the level of policy support for recycling measures. Costs and benefits of performing a behavior was evidently a matter of major concern to the public (Table 2 and 3). It is argued that emphasizing the benefits and reducing the costs of engaging in resources recycling and recovery are two most effective strategies to mobilize community support for recycling policies. For example, authorities may introduce financial incentives such as electricity tariff rebate for encouraging more recycling behaviors. The rewarding scheme makes the benefits of performing recycling behaviors explicit, and thereby increases the attractiveness of showing support to recycling policies.

The statistical results revealed that political constructs are vital to the formation of policy support. There are several suggestions for the advancement of policy formulation processes and implementation with regard to these constructs. Perceived policy effectiveness significantly influenced the level of public support for recycling policies (Table 2). Public support may be secured by providing more concrete evidence to the public, which supports the assumption that the policy is effective in goal attainment (Coombs, 1980; Eriksson, Garvill, \& Nordlund, 2006; Jagers et al., 2017). A well-established recycling chain should be developed as the case of Hong Kong. Specifically, adequate recycling facilities should be provided to facilitate 3 Rs behaviors among the public; government support to developing a flourishing recycling industry and market for processing and consuming separated 
recyclables is highly desirable. Demonstration of efficacy of recycling policy could enhance individuals' perception towards effectiveness of the policy and, in turn, the likelihood of gaining massive support.

Policy preference showed a clear and positive effect on the level of support for recycling policy, suggesting that the more the policy is keeping close tabs on the public's opinions, the higher the public support would be resulted. Mismatch between agenda setting and public preference is a major barrier for policy implementation. Only by approaching the issue at a right time with appropriate policy tools that have already been taken public preference into consideration can secure a higher level of support in the long run. With regard to participatory process, authorities need to advance current public participation mechanisms to providing the public with more policy participatory opportunities, for example, public consultation sessions. Technically, the form of public participation should be broadly participatory and inclusive. Inclusive mechanisms such as adoption of social network platforms are recommended for engagement exercises (Lee \& Kwak, 2012). In terms of manner, authorities should avoid pre-selected proposals and keep an open-minded throughout the decision-making processes. The practices facilitate consensus-building and opinion incorporation for policy formulation, which in turn establish community-wide support for policies. This study found that supporting behaviors are more likely to take place if the policy is formulated with fair procedures and just distributional outcomes have been reached. To achieve a greater degree of fairness, policy-makers may consider improving the transparency of decision-making processes by providing adequate public access to the policy information and formulation. Treating all involved parties consistently and respectfully during policy formulation processes is another possible way to reach fair policy outcomes.

\subsection{Limitations of the study}

A limitation of the present study is its opinions from tertiary-educated respondents solicited by the survey may be overrepresented relative to the population. Future studies may replicate the study by using a more equally distributed sample size. Second, path relationship between participatory process and policy support was found to be negative, a result which contradicts to the argument suggested by ample literature that there is a positive association between the two variables. To clarify the correlation, indicators of participatory process need further review. Another possible explanation is that participatory process may be influenced by other political constructs and thus has an indirect effect on policy support. Third, this study aims to evaluate the direct relationships between psychological and political factors on policy support. It is acknowledged that inter-relationships may exist among identified factors. Future studies may therefore examine moderating or mediating effect of these factors on policy support for the advancement of theoretical and conceptual model building.

\section{Conclusions}

This study rejuvenated the discussion of policy support from the public by systematically identifying psychological and political factors. A conceptual model integrating these factors was developed for investigating the phenomenon. Empirical results indicated that the conceptual model has moderate predictability of policy support. In addition to psychological attributes, the majority of identified political factors were significantly associated with the level of policy support, implying that policy support is driven by both psychological attributes and political factors. Furthermore, variance in policy support increased by adding political factors into the psychological model. Notably, policy features are more important 
than psychological attributes in contributing to policy support. The study confirmed the importance of political side in influencing policy support. The analysis that only focuses on the psychological dimension of policy support may risk unbalanced assessment of the phenomenon and cause failure in conceptual understanding. Findings also shed light on formulation and implementation processes of recycling policy. Specifically, providing adequate recycling facilities and developing a recycling chain to convince the public that participating in recycling practices is feasible for effective waste minimization and environmental protection. Besides, introducing more public consultation sessions during formulation processes is likely to reach a fair and responsive recycling policy with greater public support. Authorities are also suggested to make use of various means such as social network platforms to collate feedback and views from different social groups. Regarding the effects of psychological attributes on policy support, education and promotional campaigns for changing individuals' attitude towards recycling policy and prescribed course of actions remain essential to gaining public acceptance and support for the policy. Setting up rewarding schemes and providing financial incentives to participants engaging in recycling activities also help secure more public support for recycling policies. 
Appendix A. Questionnaire items

\begin{tabular}{|c|c|c|}
\hline Constructs/variables & \multicolumn{2}{|c|}{ Indicators/questionnaire items } \\
\hline \multirow{6}{*}{$\begin{array}{l}\text { Attitude } \\
\text { (ATTD) }\end{array}$} & ATTD1 & Recycling is good. \\
\hline & ATTD2 & Recycling is useful. \\
\hline & ATTD3 & Recycling is rewarding. \\
\hline & ATTD4 & Recycling is responsible. \\
\hline & ATTD5 & Recycling is sensible. \\
\hline & ATTD6 & Recycling is hygienic. \\
\hline \multirow{4}{*}{$\begin{array}{l}\text { Social influences } \\
\text { (SI) }\end{array}$} & SI1 & Most people who are important to me think I should recycle. \\
\hline & SI2 & Most people who are important to me would approve of me recycling. \\
\hline & SI3 & Media influences me to recycle recyclables. \\
\hline & $\mathrm{SI} 4$ & Environmental groups influence me to recycle recyclables. \\
\hline \multirow{6}{*}{$\begin{array}{l}\text { Perceived benefits } \\
\text { (PB) }\end{array}$} & PB1 & Recycling garbage saves energy. \\
\hline & PB2 & Recycling garbage saves money. \\
\hline & PB3 & Recycling garbage creates a better environment for future generations. \\
\hline & PB4 & Recycling garbage helps to protect the environment. \\
\hline & PB5 & Recycling garbage reduces the amount of waste that goes into landfill. \\
\hline & PB6 & Recycling garbage preserves natural resources. \\
\hline \multirow{4}{*}{$\begin{array}{l}\text { Past behaviour } \\
\text { (PBEV) }\end{array}$} & PBEV1 & I have recycled my recyclables in the past 4 weeks. \\
\hline & PBEV2 & I have been recycling my recyclables regularly in the past 4 weeks. \\
\hline & PBEV3 & I have recycling behavior at home. \\
\hline & PBEV4 & I have recycling behaviour at work / school. \\
\hline \multirow{8}{*}{$\begin{array}{l}\text { Place attachment } \\
\text { (PA) }\end{array}$} & PA1 & I like living in Hong Kong. \\
\hline & PA2 & I feel attached to Hong Kong. \\
\hline & PA3 & I would regret having to move to another city. \\
\hline & PA4 & When I've been away for a while, I really want to come back. \\
\hline & PA5 & I feel at home in Hong Kong. \\
\hline & PA6 & When I'm away, I miss Hong Kong. \\
\hline & PA7 & This is my favorite city to live in. \\
\hline & PA8 & When I'm away, I'm happy to come back. \\
\hline \multirow{5}{*}{$\begin{array}{l}\text { Perceived policy } \\
\text { effectiveness } \\
(\mathrm{PPE})\end{array}$} & PPE1 & The waste separation bins provided by the Government are sufficient to facilitate recycling. \\
\hline & PPE2 & The Government provides clear guidelines on recycling. \\
\hline & PPE3 & The Plastic Shopping Bag (PSB) levy is effective in encouraging recycling. \\
\hline & PPE4 & The Government's promotion effectively informs me the importance of recycling. \\
\hline & PPE5 & The Government's promotion encourages me to recycle. \\
\hline \multirow{4}{*}{$\begin{array}{l}\text { Political trust } \\
\text { (T) }\end{array}$} & T1 & You can trust the Government to do what is right. \\
\hline & $\mathrm{T} 2$ & $\begin{array}{l}\text { The Government has produced outcomes that met most citizens' preferences even if the authorities were } \\
\text { exposed to minimum supervision or scrutiny. }\end{array}$ \\
\hline & T3 & The Government is run for the benefit of all the people. \\
\hline & T4 & The Government does not waste money we pay in taxes. \\
\hline \multirow[t]{6}{*}{$\begin{array}{l}\text { Fairness } \\
\text { (FAIR) }\end{array}$} & FAIR1 & $\begin{array}{l}\text { The Government shows a high degree of transparency throughout recycling policy decision-making } \\
\text { processes. }\end{array}$ \\
\hline & FAIR2 & $\begin{array}{l}\text { The Government provides the public with adequate means for expressing views on recycling policy } \\
\text { throughout decision- making processes. }\end{array}$ \\
\hline & FAIR3 & $\begin{array}{l}\text { The Government provides the public with a fair platform for expressing views on recycling policy } \\
\text { throughout decision-making processes. }\end{array}$ \\
\hline & FAIR4 & Current waste management charging schemes (i.e., Producer Pays Principle) are fair. \\
\hline & FAIR5 & Current waste management charging mechanism (i.e., quantity-based charging) is fair. \\
\hline & FAIR6 & $\begin{array}{l}\text { Under current policy framework, members of our society share responsibility for recycling by fair } \\
\text { principles. }\end{array}$ \\
\hline \multirow{3}{*}{$\begin{array}{l}\text { Policy preference } \\
\text { (PPRE) }\end{array}$} & PPRE1 & The Government must give priority to solving recycling management. \\
\hline & PPRE2 & The Government should allocate more financial resources on recycling management. \\
\hline & PPRE3 & The Government should allocate more land resources on recycling management. \\
\hline \multirow{4}{*}{$\begin{array}{l}\text { Participatory } \\
\text { process } \\
(\mathrm{PP})\end{array}$} & PP1 & $\begin{array}{l}\text { Current policy consultation mechanisms ensure that there would be a board range of representative } \\
\text { participating in policy decision-making processes. }\end{array}$ \\
\hline & PP2 & $\begin{array}{l}\text { Under current policy consultation mechanisms, citizens are allowed to participate in decision-making in } \\
\text { an early stage. }\end{array}$ \\
\hline & PP3 & $\begin{array}{l}\text { Current policy consultation mechanisms ensure that public's views would be taken into account during } \\
\text { decision-making processes. }\end{array}$ \\
\hline & PP4 & $\begin{array}{l}\text { Current policy consultation mechanisms enable the public to understand interests and concerns of } \\
\text { different stakeholders. }\end{array}$ \\
\hline \multirow{8}{*}{$\begin{array}{l}\text { Policy support } \\
\text { (PS) }\end{array}$} & PS1 & I support the implantation of Plastic Shopping Bag (PSB) levy to all retail stores in Hong Kong. \\
\hline & PS2 & I support the introduction of Municipal Solid Waste Charging Scheme. \\
\hline & PS3 & I support the charging scheme on construction waste (e.g. surplus materials from renovation). \\
\hline & PS4 & I support extending the producer responsibility to other recyclables (e.g. packaging materials, tyres). \\
\hline & PS5 & I support earmarking funding to enhance publicity work and education campaigns on waste reduction. \\
\hline & PS6 & I support establishing the Recycling Fund to promote the development of local recycling industry. \\
\hline & PS7 & I support the development of EcoPark for the local recycling industry. \\
\hline & PS8 & I support the Government to invest in recycling infrastructure. \\
\hline
\end{tabular}

Page 20 of 27 
Appendix B. Measurement model

\begin{tabular}{|c|c|c|c|c|}
\hline Construct & Indicators & $\begin{array}{l}\text { Factors } \\
\text { loadings }\end{array}$ & $\begin{array}{c}\text { Average } \\
\text { variance } \\
\text { extracted }\end{array}$ & $\begin{array}{l}\text { Composite } \\
\text { reliability }\end{array}$ \\
\hline \multirow[t]{6}{*}{ Attitude (ATTD) } & ATTD1 & 0.848 & 0.632 & 0.911 \\
\hline & ATTD2 & 0.782 & & \\
\hline & ATTD3 & 0.860 & & \\
\hline & ATTD4 & 0.746 & & \\
\hline & ATTD5 & 0.853 & & \\
\hline & ATTD6 & 0.660 & & \\
\hline \multirow[t]{4}{*}{ Social influences (SI) } & SI1 & 0.817 & 0.527 & 0.814 \\
\hline & $\mathrm{SI} 2$ & 0.772 & & \\
\hline & $\mathrm{SI} 3$ & 0.572 & & \\
\hline & $\mathrm{SI} 4$ & 0.720 & & \\
\hline \multirow[t]{6}{*}{ Perceived benefits (PB) } & PB1 & 0.783 & 0.603 & 0.901 \\
\hline & PB2 & 0.662 & & \\
\hline & PB3 & 0.803 & & \\
\hline & PB4 & 0.826 & & \\
\hline & PB5 & 0.753 & & \\
\hline & PB6 & 0.819 & & \\
\hline \multirow[t]{4}{*}{ Past behavior (PBEV) } & PBEV1 & 0.886 & 0.699 & 0.901 \\
\hline & PBEV2 & 0.889 & & \\
\hline & PBEV3 & 0.886 & & \\
\hline & PBEV4 & 0.660 & & \\
\hline \multirow[t]{8}{*}{ Place attachment (PA) } & PA1 & 0.816 & 0.629 & 0.930 \\
\hline & PA2 & 0.840 & & \\
\hline & PA3 & 0.548 & & \\
\hline & PA4 & 0.845 & & \\
\hline & PA5 & 0.803 & & \\
\hline & PA6 & 0.811 & & \\
\hline & PA7 & 0.805 & & \\
\hline & PA8 & 0.833 & & \\
\hline \multirow[t]{5}{*}{ Perceived policy effectiveness (PPE) } & PPE1 & 0.716 & 0.628 & 0.894 \\
\hline & PPE2 & 0.798 & & \\
\hline & PPE3 & 0.763 & & \\
\hline & PPE4 & 0.832 & & \\
\hline & PPE5 & 0.845 & & \\
\hline \multirow[t]{4}{*}{ Political trust $(\mathrm{T})$} & $\mathrm{T} 1$ & 0.925 & 0.816 & 0.947 \\
\hline & $\mathrm{T} 2$ & 0.902 & & \\
\hline & T3 & 0.926 & & \\
\hline & $\mathrm{T} 4$ & 0.858 & & \\
\hline \multirow[t]{6}{*}{ Fairness (FAIR) } & FAIR1 & 0.720 & 0.552 & 0.881 \\
\hline & FAIR2 & 0.729 & & \\
\hline & FAIR3 & 0.744 & & \\
\hline & FAIR4 & 0.751 & & \\
\hline & FAIR5 & 0.778 & & \\
\hline & FAIR6 & 0.731 & & \\
\hline \multirow[t]{3}{*}{ Policy preference (PPRE) } & PPRE1 & 0.782 & 0.708 & 0.879 \\
\hline & PPRE2 & 0.895 & & \\
\hline & PPRE3 & 0.843 & & \\
\hline \multirow[t]{4}{*}{ Participatory process (PP) } & PP1 & 0.897 & 0.786 & 0.936 \\
\hline & PP2 & 0.891 & & \\
\hline & PP3 & 0.902 & & \\
\hline & PP4 & 0.855 & & \\
\hline \multirow[t]{8}{*}{ Policy support (PS) } & PS1 & 0.670 & 0.513 & 0.894 \\
\hline & PS2 & 0.737 & & \\
\hline & PS3 & 0.693 & & \\
\hline & PS4 & 0.703 & & \\
\hline & PS5 & 0.662 & & \\
\hline & PS6 & 0.775 & & \\
\hline & PS7 & 0.764 & & \\
\hline & PS8 & 0.717 & & \\
\hline
\end{tabular}


Appendix C. Correlations among the constructs

\begin{tabular}{|c|c|c|c|c|c|c|c|c|c|c|c|}
\hline Construct & ATTD & SI & PB & PBEV & PA & PPE & $\mathbf{T}$ & FAIR & PPRE & PP & PS \\
\hline Attitude (ATTD) & 0.795 & & & & & & & & & & \\
\hline Social influences (SI) & 0.309 & 0.726 & & & & & & & & & \\
\hline Perceived benefits (PB) & 0.537 & 0.337 & 0.776 & & & & & & & & \\
\hline Past behavior (PBEV) & 0.348 & 0.408 & 0.356 & 0.836 & & & & & & & \\
\hline Place attachment (PA) & 0.104 & 0.175 & 0.219 & 0.143 & 0.793 & & & & & & \\
\hline Perceived policy effectiveness (PPE) & 0.108 & 0.347 & 0.247 & 0.225 & 0.318 & 0.792 & & & & & \\
\hline Political trust (T) & 0.043 & 0.186 & 0.113 & 0.065 & 0.513 & 0.590 & 0.904 & & & & \\
\hline Fairness (FAIR) & 0.243 & 0.336 & 0.259 & 0.215 & 0.352 & 0.631 & 0.515 & 0.743 & & & \\
\hline Policy preference (PPRE) & 0.338 & 0.315 & 0.409 & 0.251 & 0.245 & 0.181 & 0.107 & 0.302 & 0.842 & & \\
\hline Participatory process (PP) & 0.076 & 0.328 & 0.193 & 0.200 & 0.365 & 0.708 & 0.587 & 0.723 & 0.182 & 0.886 & \\
\hline Policy support (PS) & 0.518 & 0.311 & 0.595 & 0.333 & 0.245 & 0.304 & 0.188 & 0.424 & 0.611 & 0.243 & 0.716 \\
\hline
\end{tabular}

Note: Figures in bold are the square roots of the average variance extracted (AVE). 


\section{References}

Abrahamse, W., \& Matthies, E. (2012). Informational strategies to promote pro-environmental behaviour: Changing knowledge, awareness and attitudes. In L. Steg, et al. (Eds.), Environmental psychology: an introduction (pp. 223-32). Hoboken, United States: John Wiley and Sons Ltd.

Ajzen, I. (1991). The Theory of Planned Behavior. Organizational Behavior and Human Decision Processes, 50, 179-211.

Ajzen, I., \& Fishbein, M. (1980). Understanding attitudes and predicting social behavior. Englewood Cliffs, N.J.: Prentice-Hall.

Bamberg, S., \& Rölle, D. (2003). Determinants of people's acceptability of pricing measures: replication and extention of a causal model. In J. Schade, et al. (Eds.), Accetability of Transport Pricing Strategies (pp. 235-48). Oxford: Emerald Publishing Limited.

Barr, S. (2007). Factors Influencing Environmental Attitudes and Behaviors A U.K. Case Study of Household Waste Management. Environment and Behavior, 39(4), 435-73.

Beierle, T.C., \& Konisky, D.M. (2000). Values, conflict, and trust in participatory environmental planning. Journal of Policy Analysis and Management, 19(4), 587-602.

Bergkvist, L., \& Rossiter, J.R. (2007). The predictive validity of multiple-item versus single-item measures of the same constructs. Journal of Marketing Research, 44(2), 175-84.

Boldero, J. (1995). The prediction of household recycling of newspapers: The role of attitudes, intentions, and situational factors. Journal of Applied Social Psychology, 25(5), 440-62.

Brehm, J.M., Eisenhauer, B.W., \& Krannich, R.S. (2006). Community Attachments as Predictors of Local Environmental Concern The Case for Multiple Dimensions of Attachment. American Behavioral Scientist, 50(2), 142-65.

Campbell, D.T., \& Fiske, D.W. (1959). Convergent and discriminant validation by the multitraitmultimethod matrix. Psychological Bulletin, 56(2), 81-105.

Census and Statistics Department. (2011). 2011 Hong Kong Population Census. Retrieved 23 June, 2017, from http://www.census2011.gov.hk/en/index.html

Chan, K. (1998). Mass communication and pro-environmental behaviour: Waste recycling in Hong Kong. Journal of Environmental Management, 52(4), 317-25.

Chen, M.-F., \& Tung, P.-J. (2010). The Moderating Effect of Perceived Lack of Facilities on Consumers' Recycling Intentions. Environment and Behavior, 42(6), 824-44.

Cheng, J.Y.S. (2014). New Trends of Political Participation in Hong Kong. In J.Y.S. Cheng (Ed.), New Trends of Political Participation in Hong Kong (pp. 3-34). Hong Kong: City University of Hong Kong Press.

Cherry, T.L., Kallbekken, S., \& Kroll, S. (2012). The acceptability of efficiency - enhancing environmental taxes, subsidies an regulation: An experimental investigation. Environmental Science \& Policy, 16, 90-96.

Cheung, C.-f. (2013, 26 September). The great green debate: Charge entire buildings a waste levy, or individuals?, News. South China Morning Post. Retrieved from http://www.scmp.com/news/hong-kong/article/1317759/great-green-debate-charge-entirebuildings-waste-levy-or-individuals

Cheung, S.F., Chan, D.K.-S., \& Wong, Z.S.-Y. (1999). Reexamining the Theory of Planned Behavior in Understanding Wastepaper Recycling. Environment and Behavior, 31(5), 587-612.

Chin, W.W. (1998). Commentary: Issues and opinion on structural equation modeling. MIS Quarterly, 22(1), vii-xvi.

Cialdini, R.B., Kallgren, C.A., \& Reno, R.R. (1991). A Focus Theory of Normative Conduct: A Theoretical Refinement and Reevaluation of the Role of Norms in Human Behavior. Advances in Experimental Social Psychology, 24, 201-34.

Cialdini, R.B., \& Trost, M.R. (1998). Social Influence: social norms conformity and compliance. In D.T. Gibert, et al. (Eds.), The Handbook of Social Psychology (pp. 151-92). New York, NY, US: McGraw-Hill.

Clayton, S. (1998). Preference for macrojustice versus microjustice in environmental decisions. Environment and Behavior, 30(2), 162-83. 
Clayton, S. (2000). New ways of thinking about environmentalism: Models of justice in the environmental debate. Journal of Social Issues, 56(3), 459-74.

Cohen, J. (1988). Statistical Power Analysis for the Behavioral Sciences. Mahwah, United States: Lawrence Erlbaum Associates.

Coombs, F.S. (1980). The bases of noncompliance with a policy. Policy Studies Journal, 8(6), 885-92.

Costanzo, M., Dane, A., Elliot, A., \& Pettigrew, T. (1986). Energy conservation behavior: The difficult path from information to action. American Psychologist, 41(5), 521-28.

Dahab, D.J., Gentry, J.W., \& Su, W. (1995). New Ways to Reach Non-Recyclers: an Extension of the Model of Reasoned Action to Recycling Behaviors. Advances in Consumer Research, 22, 251-56.

Daley, D.M. (2013). Public Participation, Citizen Engagement, and Environmental Decision Making In S. Kamieniecki, et al. (Eds.), The Oxford Handbook of U.S. Environmental Policy (pp. 487-503). Oxford; New York: Oxford University Press.

Daneshvary, N., Daneshvary, R., \& Schwer, R.K. (1998). Solid-waste recycling behavior and support for curbside textile recycling. Environment and Behavior, 30, 144-61.

Daniels, D.P., Krosnick, J.A., Tichy, M.P., \& Tompson, T. (2013). Public Opinion on Environmental Policy in the United States. In S. Kamieniecki, et al. (Eds.), The Oxford Handbook of U.S. Environmental Policy (pp. 461-86). Oxford; New York: Oxford University Press.

Davies, J., Foxall, G.R., \& Pallister, J. (2002). Beyond the Intention-An Integrated Model of Recycling. Marketing Theory, 2(1), 29-113.

de Groot, J.I.M., \& Schuitema, G. (2012). How to make the unpopular popular? Policy characteristics, social norms and the acceptability of environmental policies. Environmental Science \& Policy, 19-20, 100-07.

Dunne, L., Convery, F.J., \& Gallagher, L. (2008). An investigation into waste charges in Ireland, with emphasis on public acceptability. Waste Management, 28(12), 2826-34.

Eagly, A.H., \& Chaiken, S. (1992). The Psychology of Attitudes. San Diego, CA: Harcourt Brace Janovich.

Easton, D. (1975). A re-assessment of the concept of political support. British Journal of Political Science, 5(4), 435-57.

Elmore, R.F. (1987). Instruments and Strategy in Public Policy. Policy Studies Review, 7(1), 174-86.

Environmental Protection Department. (2016). Waste. Retrieved 01 June, 2016, from http://www.epd.gov.hk/epd/english/environmentinhk/waste/waste maincontent.html

Environmental Protection Department. (2017). Monitoring of Solid Waste in Hong Kong Waste Statistics for 2015. Hong Kong: Environmental Protection Department, The Government of HKSAR.

Eriksson, L., Garvill, J., \& Nordlund, A.M. (2006). Acceptability of travel demand management measures: The importance of problem awareness, personal norm, freedom, and fairness. Journal of Environmental Psychology, 26, 15-26.

Eriksson, L., Garvill, J., \& Nordlund, A.M. (2008). Acceptability of single and combined transport policy measures: The importance of environmental and policy specific beliefs. Transportation Research A: Policy and Practice, 42(8), 1117-28.

Fielding, K.S., McDonald, R., \& Louis, W.R. (2008). Theory of planned behaviour, identity and intentions to engage in environmental activism. Journal of Environmental Psychology, 28(4), 318-26.

Fishbein, M., \& Ajzen, I. (1975). Belief, attitude, intention, and behavior: an introduction to theory and research. Reading, Mass.: Addison-Wesley Pub. Co.

Fornell, C., \& Larcker, D.F. (1981). Evaluating Structural Equation Models with unobservable variables and measurement error. Journal of Marketing Research, 18(1), 39-50.

Garneet, K., \& Cooper, T. (2014). Effective dialogue: Enhanced public engagement as a legitimising tool for municipal waste management decision-making. Waste Management, 34(12), 2709-26.

Gifford, R., \& Sussman, R. (2012). Environmental Attitudes. In S. Clayton (Ed.), The Oxford Handbook of Environmental and Conservation Psychology (pp. 65-80). New York: Oxford University Press.

Giuliani, M.V. (2003). Theory of attachment and place attachment. In M. Bonnes, et al. (Eds.), Psychological theories for environmental issues (pp. 137-70). Aldershot: Ashgate. 
Hair, J.F., Hult, G.T.M., Ringle, C.M., \& Sarstedt, M. (2013). A Primer on Partial Least Squares Strucgural Equation Modeling (PLS-SEM). Thousand Oaks, California: SAGE Publications.

Hair, J.F., Ringle, C.M., \& Sarstedt, M. (2011). PLS-SEM: Indeed a silver bullet. Journal of Marketing Theory and Practice, 19(2), 139-52.

Harring, N. (2013). Understanding the Effects of Corruption and Political Trust on Willingness to Make Economic Sacrifices for Environmental Protection in a Cross-National Perspective. Social Science Quarterly, 94(3), 660-71.

Harring, N., \& Jagers, S.C. (2013). Should we trust in values? Explaining public support for proenvironmental taxes. Sustainability, 5(1), 210-27.

Hetherington, M.J. (2005). Why trust matters: declining political trust and the demise of American Liberalism. Princeton, NJ; Oxford: Princeton University Press.

Hidalgo, M.C., \& Hernández, B. (2001). Place Attachment: Conceptual and empirical questions. Journal of Environmental Psychology, 21(3), 273-81.

Hine, D.W., Kormos, C., \& Marks, A.D.G. (2016). Agree to Disgree A Practical Guide to Conducting Survey Research in Environmental Psychology. In R. Gifford (Ed.), Research method for environmental psychology. Hoboken: Wiley.

Innes, J.E., \& Booher, D.E. (2004). Reframing public participation: strategies for the 21 st century. Planning Theory \& Practice, 5(4), 419-36.

Jagers, S.C., Matti, S., \& Nilsson, A. (2017). How exposure to policy tools transforms the mechanisms behind public acceptability and acceptance-The case of the Gothenburg congestion tax. International Journal of Sustainable Transportation, 11(2), 109-19.

Jakobsson, C., Fujii, S., \& Gärling, T. (2000). Determinants of private car users' acceptance of road pricing. Transport Policy, 7(2), 153-58.

Jennings, W., \& Wlezien, C. (2015). Preferences, Problems and Representation. Political Science Research and Methods, 3(3), 659-81.

Jöreskog, K.G., \& Sörbom, D. (1989). LISREL 7: a guide to the program and applications. Chicago, Ill: SPSS.

Kallbekken, S., \& Sælen, H. (2011). Public acceptance for environmental taxes: Self-interest, environmental and distributional concerns. Energy Policy, 39(5), 2966-73.

Kals, E., \& Russell, Y. (2001). Individual conceptions of justice and their potential for explaining proenvironmental decision making. Social Justice Research, 14(4), 367-85.

Keramitsoglou, K.M., \& Tsagarakis, K.P. (2013). Public participation in designing a recycling scheme towards maximum public acceptance. Resources, Conservation and Recycling, 70, $55-67$.

Kim, J., Schmöcker, J.-D., Fujii, S., \& Noland, R.B. (2013). Attitudes towards road pricing and environmental taxation among US and UK students. Transportation Research A: Policy and Practice, 48, 50-62.

Kingdon, J.W. (1995). Agendas, alternatives, and public policies. New York: HarperCollins College Publishers.

Knussen, C., Yule, F., MacKenzie, J., \& Wells, M. (2004). An analysis of intentions to recycle household waste: The roles of past behaviour, perceived habit, and perceived lack of facilities. Journal of Environmental Psychology, 24(2), 237-46.

Kollmann, A., \& Reichl, J. (2015). How Trust in Governments Influences the Acceptance of Environmental Taxes. In F. Schneider, et al. (Eds.), Political Economy and Instruments of Environmental Politics (pp. 53-70). Cambridge, Massachusetts: MIT Press.

Kollmuss, A., \& Agyeman, J. (2002). Mind the gap: why do people act environmentally and what are the barriers to pro-environmental behavior? Environmental Education Research, 8(3), 239-60.

Konisky, D.M., Milyo, J., \& Richardson, L.E. (2008). Environmental policy attitudes: issues, geographical scale, and political trust. Social Science Quarterly, 89(5), 1066-85.

Kyselá, E. (2015). Acceptability of Environmental Policies in the Czech Republic: A Comparison with Willingness to Make Economic Sacrifices. Sociální studia/Social Studies, 12(3), 179-96.

Lee, E.W.Y., Chan, E.Y.M., Chan, J.C.W., Cheung, P.T.Y., Lam, W.F., \& Lam, W.-m. (2013). Municipal solid waste management Public policymaking in Hong Kong: civic engagement and state-society relations in a semi-democracy (pp. 83-96). Milton Park, Abingdon, Oxon: Routledge. 
Lee, G., \& Kwak, Y.H. (2012). An open government maturity model for social media-based public engagement. Government Information Quarterly, 29(4), 492-503.

Lee, Y.-J., De Young, R., \& Marans, R.W. (1995). Factors Influencing Individual Recycling Behavior in Office Settings A Study of Office Workers in Taiwan. Environment and Behavior, 27(3), 380-403.

Lima, M.L. (2006). Predictors of Attitudes Towards the Construction of a Waste Incinerator: Two Case Studies. Journal of Applied Social Psychology, 36(2), 441-66.

Low, S.M., \& Altman, I. (1992). Place attachment: a conceptual inquiry. In I. Altman, et al. (Eds.), Place attachment (pp. 1-12). New York: Plenum Press.

Lubell, M. (2003). Collaborative institutions, belief-systems, and perceived policy effectiveness. Political Research Quarterly, 56(3), 309-23.

Luyet, V., Schlaepfer, R., Parlange, M.B., \& Alexandre, B. (2012). A framework to implement Stakeholder participation in environmental projects. Journal of Environmental Management, $111,213-19$.

Ohnuma, S., Hirose, Y., Karasawa, K., Yorifuji, K., \& Sugiura, J. (2005). Why do residents accept a demanding rule?: faireness and social benefit as determinants of approoval of a recycling system. Japanese Psychological Research, 47(1), 1-11.

Ouellette, J.A., \& Wood, W. (1998). Habit and Intention in Everyday Life: The Multiple Processes by Which Past Behavior Predicts Future Behavior. Psychological Bulletin, 124(1), 54-74.

Page, B.I., \& Shapiro, R.Y. (2010). The Rational Public: Fifty Years of Trends in Americans' Policy Preferences. United States: University of Chicago Press.

Petts, J. (2000). Municipal Waste Management: Inequities and the Role of Deliberation. Risk Analysis, 20(6), 821-32.

Petts, J. (2001). Evaluating the Effectiveness of Deliberative Processes: Waste Management Casestudies. Journal of Environmental Planning and Management, 44(2), 207-26.

Rahardyan, B., Matsuto, T., Kakuta, Y., \& Tanaka, N. (2004). Resident's concerns and attitudes towards Solid Waste Management facilities. Waste Management, 24(5), 437-51.

Rasinski, K.A., Smith, T.W., \& Zuckerbraun, S. (1994). Fairness Motivations and Tradeoffs Underlying Public Support for Government Environmental Spending in Nine Nations. Journal of Social Issues, 50(3), 179-97.

Rauwald, K.S., \& Moore, C.F. (2002). Environmental Attitudes as Predictors of Policy Support across Three Countries. Environment and Behavior, 34(6), 709-39.

Reed, M.S. (2008). Stakeholder participation for environmental management: A literature review. Biological Conservation, 141(10), 2417-31.

Renn, O. (2006). Participatory processes for designing environmental policies. Land Use Policy, 23(1), 34.

Ringle, C.M., Wende, S., \& Becker, J.-M. (2015). SmartPLS Release: 3. from www.smartpls.com

Scannell, L., \& Gifford, R. (2010). The relations between natural and civic place attachment and proenvironmental behavior. Journal of Environmental Psychology, 30, 289-97.

Schneider, A., \& Ingram, H. (1990). Behavioral assumptions of policy tools. The Journal of Politics, 52(02), 510-29.

SCMP Editorial. (2014, 10 April). Time running out on waste charging scheme, Editorial. South China Morning Post. Retrieved from http://www.scmp.com/comment/insightopinion/article/1472227/time-running-out-waste-charging-scheme

Sidique, S.F., Lupi, F., \& Joshi, S.V. (2010). The effects of behavior and attitudes on drop-off recycling activities. Resources, Conservation and Recycling, 54(3), 163-70.

Smith, J.R., Terry, D.J., Manstead, A.S.R., \& Louis, W.R. (2007). Interaction Effects in the Theory of Planned Behavior: The Interplay of Self-Identity and Past Behavior. Journal of Applied Social Psychology, 37(11), 2726-50.

Steg, L., Dreijerink, L., \& Abrahamse, W. (2005). Factors influencing the acceptability of envergy policies: A test of VBN theory. Journal of Environmental Psychology, 25(4), 415-25.

Steg, L., \& Vlek, C. (2009). Encouraging pro-environmental behaviour: An integrative review and research agenda. Journal of Environmental Psychology, 29, 309-17.

Stern, P.C. (1992). Psychological dimensions of global environmental change. Annual Review of Psychology, 43(1), 269-302. 
Stern, P.C. (2000). New Environmental Theories: Toward a Coherent Theory of Environmentally Significant Behavior. Journal of Social Issues, 56(3), 407-24.

Stern, P.C., Dietz, T., Abel, T.D., Guagnano, G.A., \& Kalof, L. (1999). A Value-Belief-Norm Theory of Support for Social Movements: The Case of Environmentalism. Human Ecology Review, 6(2), 81-97.

Tenenhaus, M., Vinzi, V.E., Chatelin, Y.-M., \& Lauro, C. (2005). PLS path modeling. Computational Statistics \& Data Analysis, 48(1), 159-205.

Tobler, C., Visschers, V.H.M., \& Siegrist, M. (2012). Addressing climate change: Determinants of consumers' willingness to act and to support policy measures. Journal of Environmental Psychology, 32(3), 197-207.

Tonglet, M., Phillips, P.S., \& Bates, M.P. (2004). Determining the drivers for householder proenvironmental behaviour: waste minimisation compared to recycling. Resources, Conservation and Recycling, 42(1), 27-48.

Triguero, A., Álvarez-Aledo, C., \& Cuerva, M.C. (2016). Factors influencing willingness to accept different waste management policies: empirical evidence from the European Union. Journal of Cleaner Production, 138(Part 1), 38-46.

Tyler, T.R. (1990). Why people obey the law: procedural justice, legitimacy and compliance. Princeton, NJ: Princeton University Press.

Tyler, T.R. (2000). Social Justice: Outcome and Procedure. International Journal of Psychology, 35(2), 117-25.

Valle, P.O.D., Rebelo, E., Reis, E., \& Menezes, J. (2005). Combining Behavioral Theories to Predict Recycling Involvement. Environment and Behavior, 37(3), 364-96.

Vaske, J.J., \& Kobrin, K.C. (2001). Place attachment and environmentally responsible behavior. The Journal of Environmental Education, 32(4), 16-21.

Vining, J., \& Ebreo, A. (1992). Predicting recycling behavior from global and specific environmental attitudes and changes in recycling opportunities. Journal of Applied Social Psychology, 22(20), 1580-607.

Vorkinn, M., \& Riese, H. (2001). Environmental concern in a local context the significance of place attachment. Environment and Behavior, 33(2), 249-63.

Wan, C., \& Shen, G.Q. (2013). Perceived policy effectiveness and recycling behaviour: The missing link. Waste Management, 33(4), 783-84.

Wan, C., Shen, G.Q., \& Choi, S. (2017). A review on political factors influencing public support for urban environmental policy. Environmental Science \& Policy, 75, 70-80.

Wan, C., Shen, G.Q., \& Yu, A. (2014). The role of perceived effectiveness of policy measures in predicting recycling behaviour in Hong Kong. Resources, Conservation and Recycling, 83, $141-51$.

Wan, C., Shen, G.Q., \& Yu, A. (2015). Key determinants of willingness to support policy measures on recycling: A case study in Hong Kong. Environmental Science \& Policy, 54, 409-18.

Wanous, J.P., Reichers, A.E., \& Hudy, M.J. (1997). Overall Job Statifaction: How Good Are SingleItem Measures? Journal of Applied Psychology, 82(2), 247-52.

Wlezien, C. (1995). The public as themostat: Dynamics of preferences for spending. American Journal of Political Science, 39(4), 980-1000.

Wong, K.K.-K. (2013). Partial Least Squares Structural Equation Modeling (PLS-SEM) Techniques Using SmartPLS. Marketing Bulletin, 24, 1-32.

Xiao, L., Zhang, G., Zhu, Y., \& Lin, T. (2017). Promoting public participation in household waste management: A survey based method and case study in Xiamen city, China. Journal of Cleaner Production, 144, 313-22.

Zannakis, M., Wallin, A., \& Johansson, L.O. (2015). Political trust and perceptions of the quality of institutional arrangements-How do they influence the public's acceptance of environmental rules. Environmental Policy and Governance, 25(6), 424-38. 